\title{
Diagnostic exploration about job satisfaction pertaining to the contractual faculty of engineering colleges and private university in developing country like India
}

\author{
Vishal Mahajan ${ }^{1, *}$, Darshan Kumar ${ }^{2}$ \\ ${ }^{\mathbf{1}}$ Assistant Professor, ${ }^{\mathbf{A}}$ Associate Professor, ${ }^{\mathbf{1}, \mathbf{2}}$ Beant College of Engineering and Technology, Gurdaspur, Punjab, ${ }^{\mathbf{R}}$ Research Scholar, Mewar \\ University, Chittorgarh, Rajasthan, India
}

*Corresponding Author: Vishal Mahajan

Email: vishal643.vm@gmail.com

\begin{abstract}
In the present worldwide, the structure of the education faces various difficulties because of the powerful idea of the environment. One of the innumerable difficulties for enlightenment structure today is to fulfil its highly skilled faculty to manage the regularly adjusting and embryonic illumination globe A faculty can do his/her utmost capability if she/he is pleased with the task. A well-satisfied faculty can utilize his/her talent for the welfare of the students. This paper explores the job satisfaction level of contract faculty, serving in government and private institutions functioning near the border area of Gurdaspur district in Punjab, India. It also focuses on the problem and exploitation which are faced by contractual faculty due to the policies adopted by the management of these engineering institutions during their career. Approximately 700 questionnaires were distributed personally for survey and through emails. Information was collected through a study of 150 faculty members of educational institutes, serving in seven governments and self-financed colleges and private universities functioning near the perimeter area of Gurdaspur. The outcomes show that there is an immediate relationship between parameters like professional development and job satisfaction. The study presumes that by giving the best workplace, the educational institutes can build the level of job satisfaction of their faculty. Analytical results of the study have been verified with the help of SPSS-16 software.
\end{abstract}

Keywords: Job satisfaction, Edification system, Contractual faculty, Rural Area, Border area.

\section{Introduction}

Numerous colleges have not been effective to perceive the estimation of strategies and job satisfaction of their workers. This prompts many getting teething inconveniences amid their booked activities in the execution. An educator is a basic component in the advancement of enlightenment structure and the desire, mission, and vision of school and college. Faculty should get together the illumination execution model settled by the college, to ensure the value of their instructing and meeting the goals of their association. To meet the standards, they require a powerful, encompassing that enables them to work generously without inconvenience, on the grounds that an inadequate encompassing may confine them from performing up to their potential. This paper plans to break down the job satisfaction of the faculty of the engineering colleges situated close to the fringe zone of Gurdaspur, Punjab in India.

\section{Literature Review}

Endeavours have been made to perceive the connection between career development, financial benefits and job satisfaction all over the globe in assorted settings throughout the years. The research is geting consideration with the section of a period on account of its vitality and impact on the general public.

The conclusion of Sanjeev (2017) looks into recommended that there was a need to develop fitting enrolment, conservation and occupation fulfilment improvement procedures for the representatives on a restrictive premise. Dev (2017) considered that work culture exhibits a positive essential association with a large portion of the measurements of representative fulfilment. He additionally said that as the work traditions wound up more grounded, the representative fulfilment likewise made strides. Pradhan (2017) proposed that HR adaptability was the spirit for any association to manage the general exchange requests in a very much coordinated approach. Raziqa and Maulabakhsh (2015) think about uncovered that workplace positively affected the activity fulfilment of representatives. Awful working conditions constrain representatives to speak to their capacities and achieve maximum capacity, so it was vital that the organizations comprehended the significance of good workplace. Danish examination prompted that a firm could upgrade its generation through the advance of physical extents of workplace (interior atmosphere) and could have a valuable brunt on firms' efficiency. Offer and Cleal (2011) assembled a model on the work fulfilment by mixing monetary factors and workplace factors to ponder the reaction of labourers in an unsafe workplace with high budgetary advantages and safe work environment and low money related advantages. The investigation demonstrated that dissimilar psychosocial and workplace factors like the work environment, social help had a straight brunt on work fulfilment and that upgrade in rewards improved the disappointment level among representatives. The administrators' availability at desperate hour, the ability to mix representatives, excite imaginative reasoning and learning of the estimation of liberality in the vision of representatives, and potential to speak with specialists, where the fundamental organizational qualities. Results demonstrated that with great and compelling administration, workers' fulfilment level was lifted, though with lesser correspondence, ability, 
disappointment level among representatives was raised (Schroffel, 1999). Catillo and Cano (2004) at work fulfilment level among employees of universities demonstrated that if proper intrigue was given to relational connections, acknowledgment and supervision, the level of occupation fulfilment would increment. Bakotic and Babic (2013) explored that for the workforce who worked underneath persevering environment, working surroundings were a critical viewpoint for work fulfilment. To show signs of improvement fulfilment of labourers working underneath dedicated environment, it was basic for the administration to advance the working conditions. This would assemble them similarly happy with the individuals who worked under consistent working conditions and consequently, as a rule execution would support. Research in telecom segment by Tariq et al. (2013) demonstrated that there were different factors like workload, compensation, worry in the working environment and clashes with family because of employment drove a specialist towards frustration. At closing stage, these free factors affected hurtfully on hierarchical execution, which was critically disposed by these variables.

Chandrasekar (2011) watched that an association needed to offer idea to build a work surroundings that upgraded the capacity of workforce to form into a more productive keeping in mind the end goal to augment the benefits for associations. Additionally the examination, questioned that human to human correspondences and connections were playing further overwhelming capacity in the general occupation fulfilment as opposed to riches though administration abilities, time and vitality. Raziqa and Raheela Maulabakhsh (2014) elucidated significance of the effect of the idealistic working surroundings on work satisfaction over the long haul. A. Ianioglo and T. Polajeva (2017) watched that financial security encourages the accomplishment of the powerful parameters of wandering activity. S. Peng et al. (2017) clarifies that adaptable and non-questionable specialized techniques should be made and this encourages the productive administration of shared guide exercises.

Positioned on the above writing, the reasonable model tried in this paper which has not been executed in the previous research about contract faculty specially in developing countries like india, pakistan, srilanla, bangladesh, nepal etc. The variables which are involved basically represents the policies problems which are countered by these faculty members during their routine life. Basically its a non- trasparent discrimination of educated highly skilled labour by the administration of these instituions via medium of these policies is exhibited in Fig. 1. There are lot of laws and acts in these countries to abolish the un skilled and semi skilled labour problems but there are hardly any acts and laws to abolish the policy problems of exploitation of these highly skilled labour which resultant in frustration and danger signs for these countries. In this study the independent variables are the personnel policies of colleges, good communication between authority to teaching faculty, feeling of part of college, guidance in developing career, job evaluation system, performance appraisal system, career growth, faculty development programme, employee's future savings and grievance management system in which the teaching faculty are working within government engineering colleges, private engineering colleges and private university located at border area of Gurdaspur. Contractual faculty job satisfaction is the dependent variable. 


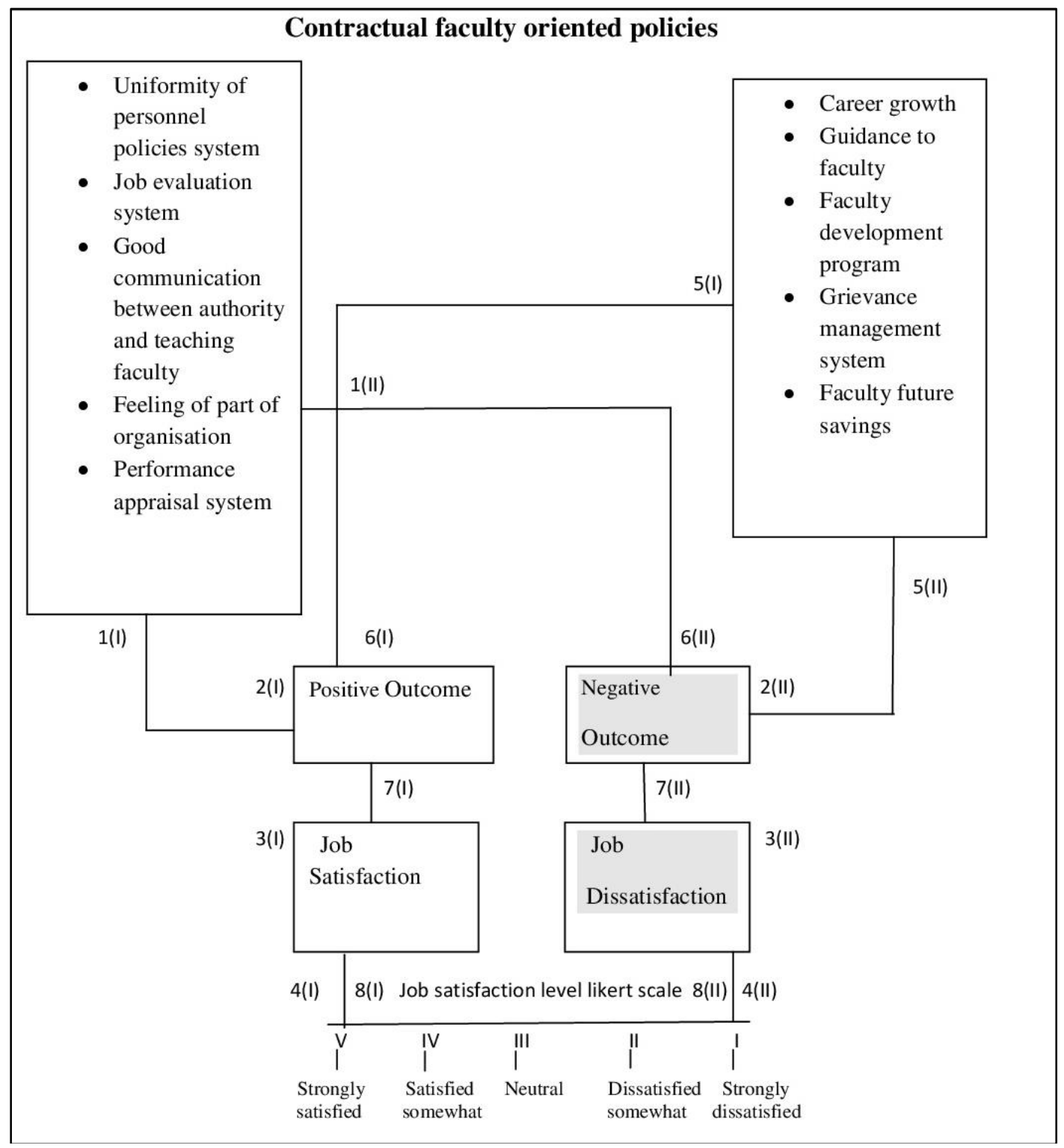

Fig. 1: A conceptual model of job satisfaction level of contractual faculty

$\mathrm{H}_{1}$ : The better contractual faculty oriented policies will increase job satisfaction

\section{Materials and Methods}

Populace and Sample Estimate: The motive of the research is to examine the connection between contractual faculty oriented policies and job satisfaction.. The information is assembled haphazardly from the faculty members of one government engineering college, six private engineering colleges and one private university located near the border area of Gurdaspur district in the state of Punjab, India, through the survey with the help of a questionnaire. Around 150 respondents were picked from different engineering colleges and one private university as explained above. The principal objective of selecting faculty members from different colleges and the private university is to get data from a differing gathering of individuals with the goal that the outcomes can be summed up to the huge gathering of the populace.

Data Mechanism and Data Investigation Technique: The questionnaire consisted of 45 things identified with questions in regards to job security, personnel policies, faculty development programmes, stress level, appraisal management system, dispute resolution system and impact of overall personnel policies on job satisfaction of contractual faculty. A five-point Likert scale is utilized to evaluate reactions going from not under any condition fulfilled, disappointed, impartial, to some degree fulfilled and unequivocally fulfilled. Various researchers assume that factual bundles are the most proper and most solid instruments for thoroughly breaking down the huge arrangement of information (Buglear, 2005). In this way, all factual examinations are executed utilizing adaptation 16.0 of "Measurable Package for Social Sciences" (SPSS). Factor examination is likewise executed as it can be utilized for the 
information comprising of test measure $n \geq 5$ (Hair et al., 2010).

\section{Findings}

The reactions accumulated through the survey of the teaching faculty have been analysed through differing factual tables and diagrams. The Cronbach's Alpha demonstrates the unwavering quality of the information utilized as a part of the poll (George, D., and Mallery, P. 2003) Table 1 explains the demographic profile of respondents and provides the information gathered from 150 teaching faculty members, $52.7 \%$ of which had a place with the age gathering of $18-30$ years, $29.3 \%$ had a place with the age gathering of $31-35$ years, $13.3 \%$ had a place with the age gathering of 36-40 years and staying $4.7 \%$ were from the age gathering of $41+$ years. Of 150 respondents, $54.7 \%$ were males, and $45.3 \%$ were females. Education institution wise, $40 \%$ respondents were from government engineering college, $48 \%$ were from private engineering colleges, and $12 \%$ were from the private university situated close to the outskirt territory of Gurdaspur. Along these results we acknowledge alternative hypothesis that better faculty oriented policies will increase job satisfaction.
Table 1 : Pictorial demographic measurements

\begin{tabular}{|l|l|c|c|}
\hline \multicolumn{4}{|c|}{ Demographic Profile } \\
\hline & & Frequency & \%age \\
\hline \multirow{4}{*}{ Age } & $18-30$ & 79 & 52.7 \\
\cline { 2 - 4 } & $31-35$ & 44 & 29.3 \\
\cline { 2 - 4 } & $36-40$ & 20 & 13.3 \\
\cline { 2 - 4 } & $41+$ & 07 & 4.7 \\
\hline \multirow{3}{*}{ Gender } & Male & 82 & 54.7 \\
\cline { 2 - 4 } & Female & 68 & 45.3 \\
\hline \multirow{3}{*}{$\begin{array}{l}\text { Engineering } \\
\text { Institution }\end{array}$} & Government & 60 & 40.0 \\
\cline { 2 - 4 } & College & & \\
\cline { 2 - 4 } & Private Colleges & 72 & 48.0 \\
\cline { 2 - 4 } & Private University & 18 & 12.0 \\
\hline
\end{tabular}

Table 2 demonstrates that for 11 inquiries of the questionnaire about Job satisfaction, the consistency was $93.3 \%$. It demonstrates that the reactions gathered with the information genuinely right to examine the relationship of contractual faculty oriented policies and other factors of job satisfaction.

Table 2: Rotated component matrix for contractual faculty oriented policies and job satisfaction variables

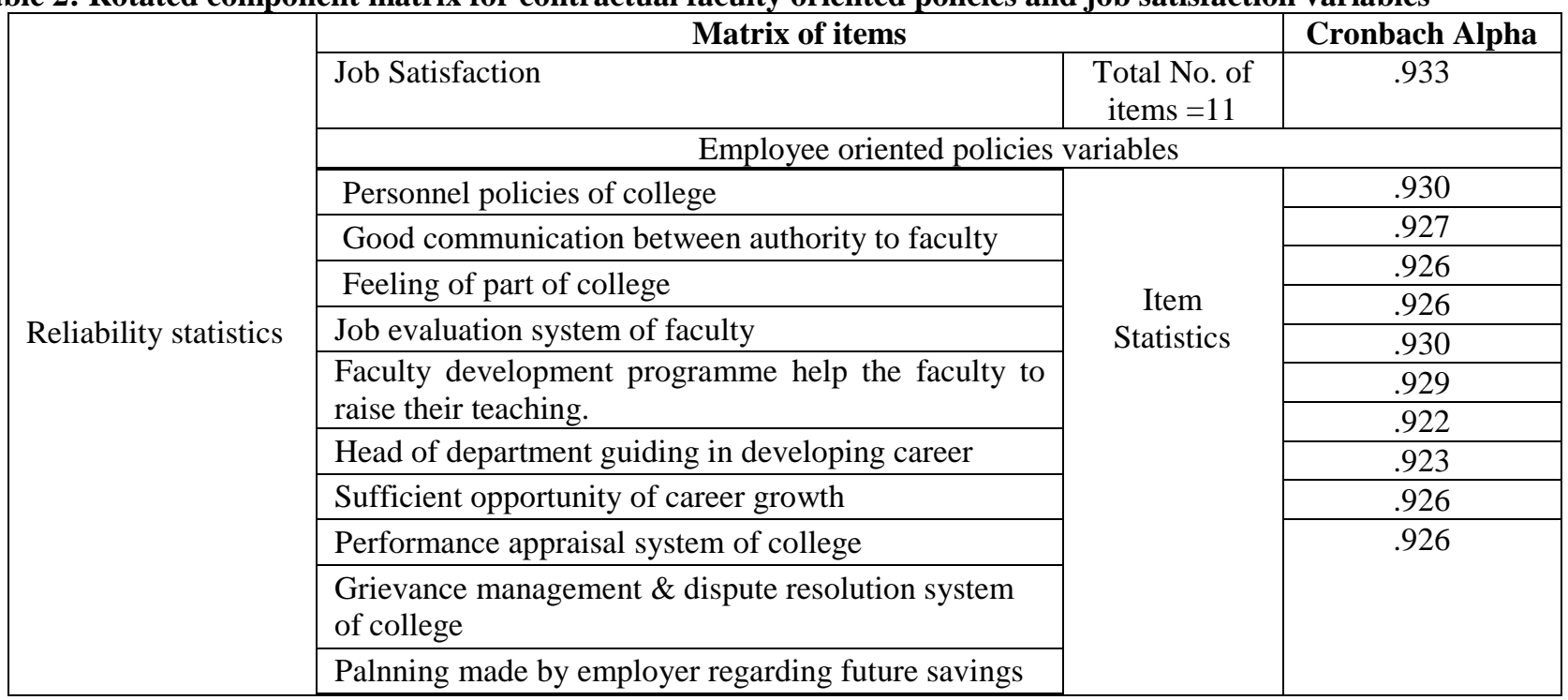

One question was removed from the factor matrix to increase reliability of Cronbach alpha. Ten questions significantly weighed down on contractual faculty oriented policies and one question weighed down on job satisfaction. The survey utilized in the investigation was analysed for unwavering quality having both principle factors. Commonly accepted rule for describing internal consistency using Cronbach alpha is $0.9 \leq \alpha$ results in excellent internal consistency, if $\alpha<0.5$ results in internal consistency then it is unacceptable (DeVellis, R.F. 2012). The cronbach alpha of parameters such as personnel policies of college and faculty development programme that helps the faculty raise their teaching skills was 0.930 , Head of the department guidance in developing career was 0.929 , There is a good communication between authority and teaching faculty was 0.927.But for other parameters such as feeling of part of college, Job evaluation system of faculty, grievance management, dispute resolution system of college and planning made by employers regarding faculty future saving, Cronbach alpha for all these parameter was 0.926 . Cronbach alpha of performance appraisal system of your college was 0.923 and for parameter like getting sufficient opportunity for career growth was 0.922 and last parameter such as satisfied with your job was 0.930 . It demonstrates that the information gathered utilizing the questionnaire has given valuable data about the assessments of faculty about the factors utilized. 
Table 3: Correlation matrix for contractual faculty oriented policies and job satisfaction

\begin{tabular}{|c|c|c|c|c|c|c|c|c|c|c|c|}
\hline & 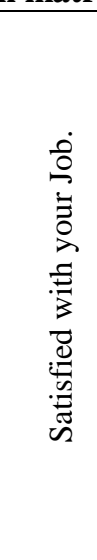 & 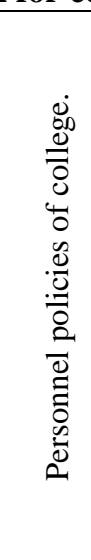 & 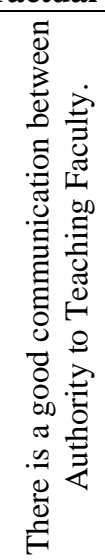 & 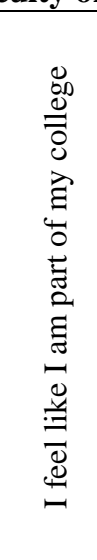 & 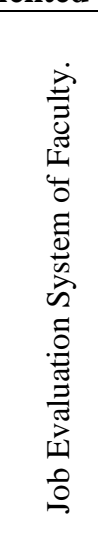 & 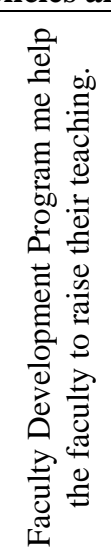 & 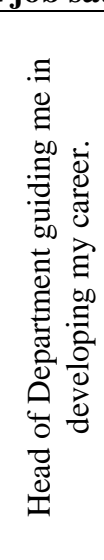 & 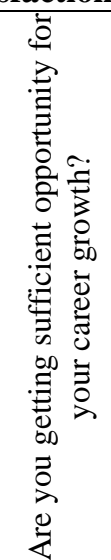 & 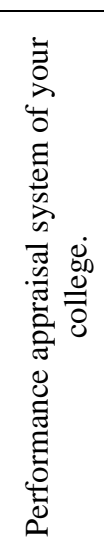 & 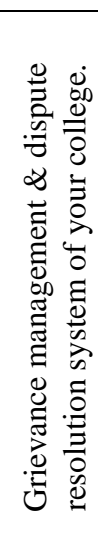 & 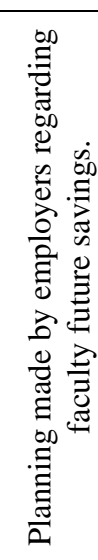 \\
\hline Job.Satisfaction & 1.000 & & & & & & & & & & \\
\hline $\begin{array}{l}\text { Personnel policies } \\
\text { of college. }\left(\mathrm{r}_{1}\right)\end{array}$ & $.358^{*}$ & 1.000 & & & & & & & & & \\
\hline $\begin{array}{l}\text { Good } \\
\text { communication } \\
\text { between authority } \\
\text { to Faculty. }\left(\mathrm{r}_{2}\right)\end{array}$ & .458 & .631 & 1.000 & & & & & & & & \\
\hline $\begin{array}{l}\text { Feeling of part of } \\
\text { college. }\left(\mathrm{r}_{3}\right)\end{array}$ & $.479 *$ & .621 & .657 & 1.000 & & & & & & & \\
\hline $\begin{array}{l}\text { Job Evaluation } \\
\text { System of } \\
\text { faculty.(}\left(\mathrm{r}_{4}\right)\end{array}$ & .513 & .556 & .579 & .571 & 1.000 & & & & & & \\
\hline $\begin{array}{l}\text { Faculty } \\
\text { Development } \\
\text { Program me help } \\
\text { the faculty to raise } \\
\left.\text { their teaching..( } \mathrm{r}_{5}\right)\end{array}$ & .529 & .385 & .424 & .538 & .659 & 1.000 & & & & & \\
\hline $\begin{array}{l}\text { Head of } \\
\text { Department } \\
\text { guiding in } \\
\text { developing } \\
\left.\text { career.(r }{ }_{6}\right)\end{array}$ & .593 & .342 & .426 & .544 & .573 & .674 & 1.000 & & & & \\
\hline $\begin{array}{l}\text { Sufficient } \\
\text { opportunity for } \\
\left.\text { career growth.( } \mathrm{r}_{7}\right)\end{array}$ & .593 & .607 & .611 & .665 & .626 & .504 & .545 & 1.000 & & & \\
\hline $\begin{array}{l}\text { Performance } \\
\text { appraisal system } \\
\text { of college. }\left(\mathrm{r}_{8}\right) \text {. }\end{array}$ & .573 & .482 & .599 & .588 & .620 & .554 & .601 & .759 & 1.000 & & \\
\hline $\begin{array}{l}\text { Grievance } \\
\text { management \& } \\
\text { dispute resolution } \\
\text { system of } \\
\text { college. }\left(\mathrm{r}_{9}\right)\end{array}$ & $.498^{*}$ & .497 & .585 & .520 & .526 & .434 & .503 & .709 & .719 & 1.000 & \\
\hline $\begin{array}{l}\text { Planning made by } \\
\text { employers } \\
\text { regarding faculty } \\
\left.\text { future saving.( } \mathrm{r}_{10}\right)\end{array}$ & .511 & .526 & .617 & .588 & .505 & .438 & .442 & .695 & .687 & .737 & 1.000 \\
\hline
\end{tabular}

$P<0.05^{*}$

Correlation analysis was performed to establish the association between contractual faculty oriented policies and job satisfaction. Contractual faculty oriented policies includes the parameters such as personnel policies of college, good communication between authority and teaching faculty, feeling of part of college, head of department guiding in developing career, job evaluation system of faculty, performance appraisal system of college, getting sufficient opportunity for career growth, faculty development programme help to raise the teaching standards, planning made by employers regarding 
contractual faculty future savings, grievance management and dispute resolution system of college. All these parameters are correlated with job satisfaction. Results shows in Table 3 that parameters like head of department guiding in developing career and getting sufficient opportunity for career growth has the huge positive association with the job satisfaction as both $\mathrm{r}_{6}$ and $\mathrm{r}_{7}$ are $=$ $0.593, \mathrm{p}<0.05$. Also, for parameters such as performance appraisal system of college, faculty development programme, job evaluation system of faculty, planning made by employers regarding faculty future savings and grievance management cum dispute resolution system of college relationship with job satisfaction are significant and positive due to $r_{8}=0.573, r_{5}=0.529, r_{4}=0.513, r_{10}=0.511$ and $r_{9}=0.498$ at $p<0.05$. The relationship of parameters such as feeling of part of college, good communication between the authority and teaching faculty and personnel policies of colleges, explains their values as $r_{3}=0.479, r_{2}=$ 0.458 and $r_{1}=0.358$. The values are significant and positive.

Table 4: Regression analysis on contractual faculty oriented policies (dependent variable - job Satisfaction)

\begin{tabular}{|c|c|c|c|}
\hline 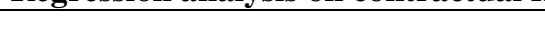 & Coefficient & Standard Error & Standardized Beta \\
\hline Intercept. & $.348 *$ & .200 & $---\left(\beta_{0}\right)$ \\
\hline Personnel policies of college & -.074 & .090 & $-.073\left(\beta_{1}\right)$ \\
\hline $\begin{array}{l}\text { Good communication } \\
\text { between authority to teaching faculty }\end{array}$ & $.070 *$ & .087 & $077\left(\beta_{2}\right)$ \\
\hline Feeling of part of college & $-.030 *$ & .091 & $-.032\left(\beta_{3}\right)$ \\
\hline Job evaluation system of faculty & $.037 *$ & .097 & $038\left(\beta_{4}\right)$ \\
\hline $\begin{array}{l}\text { Faculty development programme help } \\
\text { the faculty to raise their }\end{array}$ & $.121 *$ & .093 & $.122\left(\beta_{5}\right)$ \\
\hline $\begin{array}{l}\text { Head of department guiding in } \\
\text { developing career }\end{array}$ & $.249 *$ & .082 & $.280\left(\beta_{6}\right)$ \\
\hline $\begin{array}{l}\text { Sufficient opportunity } \\
\text { for career growth }\end{array}$ & $240 *$ & .103 & $.265\left(\beta_{7}\right)$ \\
\hline $\begin{array}{l}\text { Performance appraisal system of } \\
\text { college. }\end{array}$ & $.051 *$ & .104 & $.055\left(\beta_{8}\right)$ \\
\hline $\begin{array}{l}\text { Grievance management \& } \\
\text { dispute resolution system of college. }\end{array}$ & $-0.19 *$ & 0.85 & $-.024\left(\beta_{9}\right)$ \\
\hline $\begin{array}{l}\text { Planning made by employers } \\
\text { regarding faculty future saving. }\end{array}$ & $.098 *$ & 0.84 & $.120\left(\beta_{10}\right)$ \\
\hline
\end{tabular}

The regression analysis was conducted to define the impact of contractual faculty oriented policies (personnel policies of colleges, good communication between the authority and teaching faculty, feeling of part of college, guidance in developing a career, job evaluation system, performance appraisal system, career growth, faculty development programme, faculty future saving and grievance management system) effect on job satisfaction as shown in Table 4. The regression result discloses that factors related to contractual faculty oriented policies have a statistically significant impact on job satisfaction. The results achieved are: $R=0.694, \beta_{0}=0.348, \beta_{1}=-.073, \beta_{2}=$ $0.077, \beta_{3}=-0.032, \beta_{4}=0.038, \beta_{5}=0.122, \beta_{6}=0.280, \beta_{7}=$ $0.265, \beta_{8}=0.055, \beta_{9}=-0.024$ and $\beta_{10}=0.120$. Factors, like good communication between the authority and teaching faculty $(\mathrm{t}=0.809)$, guidance in developing a career $(\mathrm{t}=$ 3.046), job evaluation system $(\mathrm{t}=0.388)$, performance appraisal system $(\mathrm{t}=0.489)$, career growth $(\mathrm{t}=2.321)$, faculty development programme $(\mathrm{t}=1.295)$, and faculty future savings $(\mathrm{t}=1.165)$. Other factors, like: personnel policies of colleges $(\mathrm{t}=-0.816)$, the feeling of being part of college $(\mathrm{t}=-0.326)$ and grievance management system $(\mathrm{t}=$ - 0.288) $\mathrm{p}<0.05$. UN standardized coefficient demonstrates how much the reliant variables differ with autonomous variables when the independent variables are held consistent. We can test for the statistical significance of every one of the autonomous variables. It will test whether the UN standardized (or standardized) coefficients are equivalent to 0 (zero) in the table. On the off chance that $\mathrm{p}<0.05$, we can infer that the coefficients are statistically significantly different to 0 (zero).

The estimation of $\mathrm{R}=69.4 \%$. This demonstrates there is a positive straight connection between contractual faculty oriented policies and job satisfaction. Additionally, the outcome likewise demonstrates that contractual faculty oriented policies get a $48.2 \%$ share in job satisfaction that is $\mathrm{R}_{2}$. The estimation of $\mathrm{F}=1.24$, which is statistically significant at $\mathrm{P}<0.05$ and the estimation of $\mathrm{t}$ are likewise statistically significant in seven faculty oriented policy factors. Hence, we can dismiss our null hypothesis.

The regression equation that can be formed in view of the data acquired is as per the following

$Y=\beta_{0+} \beta_{1} X_{1+} \beta_{2} X_{2+} \beta_{3} X_{3+} \beta_{4} X_{4+} \beta_{5} X_{5+} \beta_{6} X_{6+} \beta_{7} X_{7+} \beta_{8}$ $X_{8+} \beta_{9} X_{9+} \beta_{10} X_{10+} E(1)$

Where

$\mathrm{Y}=$ Job Satisfaction

$\mathrm{X}_{1}=$ Personnel policies of colleges

$\mathrm{X}_{2}=$ Good communication between the authority to teaching faculty 
$\mathrm{X}_{3=}$ Feeling of part of college

$\mathrm{X}_{4=}$ Job evaluation system

$\mathrm{X}_{5=}$ Faculty development programme

$\mathrm{X}_{6=}$ Guidance in developing career

$\mathrm{X}_{7=}$ Career growth

$\mathrm{X}_{8=}$ Performance appraisal system

$\mathrm{X}_{9=}$ Grievance management system

$\mathrm{X}_{10=}$ Faculty future savings

$\mathrm{E}=$ Error Term

As $X_{1}, X 3, X_{9}$ have insignificant effect that is $\beta_{1=.} 358$ $\beta 3=.479, \quad \beta_{9}=498$ respectively at $p>0.05$, therefore, the equation reduces to

$\mathrm{Y}=0.348+.077 \mathrm{X}_{2}+.038 \mathrm{X}_{4}+.122 \mathrm{X}_{5}+.280 \mathrm{X}_{6}+.265 \mathrm{X}_{7}+.055$

$\mathrm{X}_{8}+.120 \mathrm{X}_{10}+.796$ (2)

Where $\beta_{0}=0.348$

$\beta_{2}=077$ (Good communication between authority to teaching faculty)

$\beta_{4}=.038$ (Job Evaluation system)

$\beta_{5}=.122$ (Faculty development programme)

$\beta_{6}=.280$ (Guidance in developing career)

$\beta_{7}=.265$ (Career growth opportunity)

$\beta_{8}=.055$ (Performance appraisal system)

$\beta_{10}=.120$ (Faculty future savings)

$\mathrm{E}=.0796$ (3)

Therefore, regression coefficient $\beta_{2}=.077$ indicates that job satisfaction increases by. 077 for every contract employee from the parameter of good communication between authority and faculty and $\beta_{4}=038$ indicates that job satisfaction of the parameter job evaluation system increases by. 038 and so on for other parameters. Further, it can be seen that the combined effect of $\mathrm{X}_{2}, \mathrm{X}_{4}, \mathrm{X}_{5}, \mathrm{X}_{6}, \mathrm{X}_{7}, \mathrm{X}_{8}$ and $\mathrm{X}_{10}$ on $\mathrm{Y}$ are additive. Generally dependent $\mathrm{Y}$ variable and independent variables $\mathrm{X}_{2}, \mathrm{X}_{4}, \mathrm{X}_{5}, \mathrm{X}_{6}, \mathrm{X}_{7}, \mathrm{X}_{8}$ and $\mathrm{X}_{10}$ converted to the standard scores like to say, $Z_{2}, Z_{4}, Z_{5}, Z_{6}, Z_{7}$, $Z_{8}$ and $Z_{10}$ each with mean 0 and standard deviation 1 . These analyses are based on the assumption that equation (1) includes all the important and relevant variables because if any of these are excluded, then the predictive power of the model will be reduced. Even though a variable are omitted its effect may still include if the excluded variable is correlated with one of the included variable. This way the estimated coefficient of included variables reflects both the included and the excluded variables. All the independent variables are highly correlated. Due to this estimated regression coefficient can fluctuate widely from region to region.

\section{Result and Discussion}

The investigation has demonstrated a positive connection between better contractual faculty oriented policies and job satisfaction. The teaching faculty working every one of the three divisions (government engineering college, private engineering colleges and university) has the view that better contractual faculty oriented policies assume a pivotal part in achieving job satisfaction. While the University Grant Commission of India and All India Council of Technical Education of India standards turn out to be hard and education service wind up powerful and requesting so education institutes, to function up to their utmost potential, have to make sure that their teaching faculty is functioning under faculty friendly policies.

The regression analysis results showed that contractual faculty oriented policies have the positive impact on job satisfaction as $R_{2}=48.2 \%$. Job satisfaction is upgraded by the favourable workplace which is confirmed by Lee and Brand (2005). The aftereffects of this investigation repudiated by the examination consequences of Tokuda et al. (2009) and Rafiq et al. (2012) that the workplace is adversely connected with employees' job satisfaction, though outward rewards are the best help to cause job satisfaction. Therefore, education institutes must focus towards this segment of the job. In the present investigation, it has been observed that guidance in developing the career by the head of the department and getting sufficient opportunity for career growth has a critical association with job satisfaction (the correlation coefficient value of both is 0.593 at $p<0.05)$. The study showed that good communication between the authority and teaching faculty, job evaluation system, performance appraisal system, faculty development programme, faculty future savings are positively related to job satisfaction. This perception of our investigation is bolstered by the exploration of Babin and Boles (1996), who contended that supervisory help and specialist association diminishes the work pressure. However, personnel policies of colleges, feeling of being a part of college and grievance management system do not turn out to have the significant relationship with the job satisfaction.. In this manner, it is imperative that the educational institutions recognize the requirements of their teaching faculty and help them to accomplish their professional objectives. Better faculty oriented policies increase personnel devotion, level of commitment, competency and efficiency, output, and also develop a sense of delivering excellent lectures on the part of teaching faculty which eventually increase educational institutes efficiency and reduce cost rising, which may come as a result of displeased teaching faculty.

\section{Conclusion}

Contract faculty oriented policies optimistically affect the job satisfaction of teaching faculty. Awful approaches stop faculty to work up to their capability and full potential. It is, therefore, indispensable that the educational institution perceive the significance of good faculty oriented policies. This research paper contributes towards the prosperity of society as the outcomes make mindfulness about the significance of good contract faculty oriented policies for job satisfaction of faculty regardless of its classification, whether contractual or regular faculty. The investigation impacts upon the future execution of policy for education institution close to the outskirt zone of Gurdaspur by considering contract faculty oriented policies more seriously within institutions to build the motivation and devotion level of the contractual faculty members. Faculty can achieve better results in this way. Management of the institution 
additionally guarantees that the contract faculty will work in an agreeable and open condition without discrimination or stress that would confine their performance to decrease. These policies will directly help the financial system of a country, as teaching talent will increase. The benefits of providing a good contract faculty oriented policies are great for both the education institutions and its faculty members.

\section{Conflict of Interest: None.}

\section{References}

1. Ianioglo and T. Polajeva. "The essence and phases of the comprehensive system of ensuring the economic security of enterprise". International Journal of Learning and Change, Inderscience Publishers. 2017;9(1):59-74.

2. Aiken, L., Clarke, S., and Sloane, D."Hospital staffing, organizational support and quality of care: cross-national findings". International, Journal for Quality in Health Care. 2002;50(5):87-94.

3. Arnetz, B. "Staff perception of the impact of health care transformation on quality of care". International Journal for Quality in Health Care. 1999;11(4):345-51.

4. Baah, K., and Amoako, G. K. "Application of Frederick Herzberg's Two-Factor Theory in Assessing and Understanding Employee Motivation at Work: a Ghanaian Perspective". European Journal of Business and Management. 2011;3(9):1-8.

5. Babin, J. B., and Boles, J. S. The Effects of Perceived CoWorker Involvement and Supervisor Support on Service Provider Role Stress, Performance and job Satisfaction. Journal of Retailing. 1996;72(1):57-75.

6. Bakotic, D., and Babic, T. B. "Relationship between Working Conditions and Job Satisfaction: The Case of Croatian Shipbuilding Company". International Journal of Business and Social Science, 2013;4(2):206-213.

7. Bordhan S . "A Comparative Study of Job Satisfaction and Attitude towards Education among Male and Female Teachers of Degree Colleges" International Journal of Pure and Applied Researches. 2016;1(1):ISSN: 2455-474X.

8. Buglear, J. "Quantitative Methods for Business." The A-Zof QM. Burlington: Elsevier.(2015).

9. Buhai, S., Cottini, E., and Nielseny, N. "The impact of Workplace Conditions on Firm Performance" 2008;8-13.

10. Castillo, J. X., and Cano, J. "Factors Explaining Job Satisfaction among Faculty". Journal of Agricultural Education, 2004;45(3):65-74.

11. Clark, A. E. "Job satisfaction and gender: Why are women so happy at work?" Labour economics, 1997;4(4):341-372.

12. DeVellis, R. F."Scale development: Theory and applications (Third Edition)". Thousand Oaks, CA: Sage Publications.(2012)

13. Dev $\mathrm{S}$ and Sengupta $\mathrm{S}$ "The impact of work culture on employee satisfaction-empirical evidence from the Indian banking sector" International journal of Human Resource Development and Management, Inderscience Publishers. 2017;3/4:30-246.

14. Erquhart, Joe Ann; "Job satisfaction of middle school principals in Virginia", Dissertation Abstract International, (2011) 7.

15. Gazioglu, S., and Tanselb, A. "Job Satisfaction in Britain: Individual and Job Related Factors". Applied Economics, 2006;38(10):1163-1171.

16. George, D., \& Mallery, P."Using SPSS for Windows Step by Step: A Simple Guide and Reference (4th ed.)". London: Pearson Education.(2003).
17. Hair, J. F., Black, W. C., Babin, B. J., and Anderson, R. E. "Exploratory Factor Analysis". In Multivariate Analysis, Pearson Prentice Hal,7th edition, 2010;90-151.

18. Herzberg, F., Mausne, B., and Snyderman, B."The Motivation to Work". Jhon Wiley.(1959), 157.

19. Hoppok, R., and Spielgler "Aoril. Job Satisfaction. Occupations": The Vocational Guidance Journal, 1938;16(7):636-643.

20. Howery, B. B. Teacher technology training: A study of the Impact of Educational Technology on teacher attitude and student achievement, Dissertation abstract International, 2001;62(3).

21. Kinzl, J. F., Knotzer, H., Traweger, C., Lederer, W., Heidegger, T., and Benzer, A. "Influence of working conditions on job satisfaction in anaesthetists". British Journal of Anaesthesia, 2005;94(2):211-215.

22. Kinzl, J. F., Knotzer, H., Traweger, C., Lederer, W., Heidegger, T., \& Benzer, A. "Influence of working conditions on job satisfaction in anaesthetists". British Journal of Anaesthesia, 2005;94(2):211-215.

23. Lee, S. Y., \& Brand, J. L."Effects of control over office workspace on perceptions of the work environment and work outcomes", Journal of Environmental Psychology, 2005;25:323-333.

24. M.A. Sanjeev. Age and job satisfaction: an empirical investigation among the pharmaceutical sales and marketing professionals in India" International journal of Human Resource Development and Management, Inderscience Publishers. 2017;3/4:315-332.

25. Pradhan K Rabindra, Itishree G. Kumari and Updesh "Human resource flexibility and organisation effectiveness: mediating role of organisation citizenship behaviour " International journal of Human Resource Development and Management", Inderscience Publishers 2017;3/4,.282-300.

26. Rafiq, M., Javed, M., Khan, M., \& Ahmed, M. "Effect of Rewards on Job Satisfaction Evidence From Pakistan". Interdisciplinary Journal of Contemporary Research in Business, 2012;4(1).

27. Raziqa A and Maulabakhsh $\mathrm{R}$ "Impact of Working Environment on Job Satisfaction", 2nd Global Conference on Business, Economics Management and Tourism, Prague, Czech Republic, Procedia Economics and Finance. 2015;23;717-725.

28. S. Peng et al. "A university-industry cooperation model for small and medium enterprises: the case of Chengdu KEDA Optoelectronic Technology Ltd". International Journal of Learning and Change, Inderscience Publishers, 2017;9(1):2945.

29. Sharma A "A Study of Job Satisfaction of Secondary School Teachers". Sai Om Journal of Arts and Education. 2016;3(2):7-12.

30. Tokuda,Y., Hayano, K.,Ozaki, M., Bito, S.,Yanai, H., \& Kozumi, S. The Interrelationship Between Working Conditions, Job satisfaction, and Mental Health among Hospital Physicians in Japan, A path Analysis. Industrial Health, 2009;47:166-172.

31. Trivedi M Twinkle. A Study of Job Satisfaction among Male and Female Faculties Teaching in Self-Finance and Government Colleges within Ahmedabad District, Journal of Commerce and Management. 2014:11.

How to cite this article: Mahajan V, Kumar D. Diagnostic exploration about job satisfaction pertaining to the contractual faculty of engineering colleges and private university in developing country like India. J Manag Res Anal. 2018;5(4):412-419. 